Андрусенко С.І., Бугайчук О.С., Будниченко В.Б., Подпіснов В.С. Національний транспортний університет, Київ, Украӥна

\title{
ВИКОРИСТАННЯ МЕТОДІВ УПРАВЛІННЯ РИЗИКАМИ ДЛЯ ЗМЕНШЕННЯ АВАРІЙНОСТІ НА ТРАНСПОРТІ
}

\begin{abstract}
У статті наведений аналіз нормативних документів, наукових та навчально-практичних робіт, присвячених питанням зменшення аварійності на транспорті та застосуванню методів управління ризиками для досягнення цієї мети.

Показано, що організація повинна визначити ризики та можливості, які потрібно врахувати, щоб забезпечити впевненість у тому, що підприємство може досягти запланованого результату, збільшити кількість бажаних ефектів, запобігти небажаним ефектам або зменшити їхню кількість, досягти поліпшення.

Організація має планувати та інтегрувати в процеси управління дії стосовно цих ризиків i можливостей. Необхідно оцінювати результативність таких дій.

Ризики мають бути ідентифіковані та започаткований процес аналізу ризиків. Пропонується контрольними точками процесу визнати такі: невідповідність технічного стану рухомого складу вимогам, які визначають його безпечну експлуатацію (точка 1); невідповідність дій водія вимогам правил дорожнього руху, настанов щодо експлуатації транспортного засобу, інструкцій водія (точка 2). Складається реєстр ризиків. Проводиться кількісний аналіз ризиків, де підраховується значення індикатору ризику, наприклад, відповідно до документу ГКН 00.005.009-2002. Надаються рекомендації щодо зменшення ризику шляхом ухилення від ризику (припинення діяльності, що веде до ризику) або прийняття ризику (не виконується ніяких дій для зниження ймовірності або впливу події). Подальше дослідження має бути спрямоване на розширення реєстру ризиків діяльності на транспорті та удосконалення методів оцінки запровадження в підприємстві системи управління ризиками.

Ключові слова: транспорт, безпека руху, аварійність, ризик, управління, аналіз, процес, контрольні точки, ідентифікатор ризику, реєстр ризиків.
\end{abstract}

\section{ВСТУП}

Згідно з нормативним документом [1] до колісних транспортних засобів (КТЗ), призначених для перевезення пасажирів, належать самохідні КТЗ категорії М. Їх класифікують наступним чином: $\mathrm{M}_{1}$ - колісний засіб, що призначений для перевезення пасажирів, у якому кількість місць для сидіння, крім місця водія, не перевищує восьми; $\mathrm{M}_{2}$ - колісний засіб, що призначений для перевезення пасажирів, у якому кількість місць для сидіння, крім місця водія, перевищує вісім, максимальною масою не більше ніж 5 тон; $\mathrm{M}_{3}$ - колісний засіб, що призначений для перевезення пасажирів, у якому кількість місць для сидіння, крім місця водія, перевищує вісім, максимальною масою понад 5 тон.

Такі КТЗ, а також трамваї та тролейбуси є джерелом підвищеної небезпеки. В процесі комерційної експлуатації вони здійснюють перевезення пасажирів на дорогах загального користування, де, як правило, існує велика щільність руху автомобільних потоків, що значно збільшує імовірність аварійної ситуації. Тому ця сфера є предметом регулювання на всіх рівнях господарювання в державі.

\section{АНАЛІЗ ЛІТЕРАТУРНИХ ДАНИХ ТА ПОСТАНОВКА ПРОБЛЕМИ}

Прийняті і діють ряд нормативних документів державного рівня, спрямованих на підвищення безпеки дорожнього руху [2-12]. Вирішенням питань аварійності на транспорті займаються також галузеві організації та підприємства на місцевому рівні [13-15], розробляючи та впроваджуючи відповідні нормативні документи та інструкції, спрямовані на запобігання виникнення аварійних ситуацій. Це питання знаходиться під постійним контролем відповідних органів. Так, наприклад, за даними щодо кількості транспортних пригод, які подані у звітних документах одним із транспортних підприємств міського електротранспорту, робота підприємства, оцінена згідно 3 методикою ГКН 00.005.009-2002, за деякі періоди часу була визнана незадовільною.

Проблемам зменшення кількості аварій на транспорті присвячена велика кількість наукових та практичних робіт, серед яких у певній кількості розглядаються питання впровадження та удосконалення системи управління ризиками транспортної діяльності [16-24].

Також питання управління ризиками в господарській діяльності вирішується на рівні державних та міжнародних стандартів наприклад [25-28].

Остання редакція міжнародного стандарту якості ДСТУ ISO 9001-2015 (ISO 9001:2015, IDT) «Системи управління якістю. Вимоги» передбачає планування дій стосовно ризиків і можливостей (п.6. Планування) [28]. 
Під час планування в системі управління якістю організація повинна визначити ризики та можливості, які потрібно врахувати для забезпечення впевненості в тому, що система управління якістю може досягти запланованого результату, збільшити кількість бажаних ефектів; запобігти небажаним ефектам або зменшити їхню кількість, досягти поліпшення. Організація повинна планувати дії стосовно цих ризиків і можливостей. Дії стосовно ризиків і можливостей мають бути заплановані та інтегровані в процеси системи управління якістю. Необхідно оцінювати результативність цих дій. Потрібно, щоб дії, виконувані стосовно ризиків і можливостей, були пропорційні їх потенційному впливу на відповідність продукції та послуг.

Реагування на ризики можуть охоплювати уникнення ризику, прийняття ризику, щоб скористатися можливістю, усунення джерела ризику, змінення ймовірності настання чи наслідків, розділення ризику чи збереження ризику на основі поінформованого рішення.

В наведених вище нормативних документах та роботах розглядаються різні складові діяльності, які впливають на аварійність. Існує багато методів зменшення аварійності. Як вже було зазначено вище, серед таких методів все більше уваги приділяється методам управління ризиками. Але плануванню заходів, спрямованих на запровадження на конкретних підприємствах транспорту методів керування ризиками виникнення транспортних пригод, ще не приділяєтеся достатньо уваги.

\section{ЦІЛЬ ТА ЗАДАЧІ ДОСЛІДЖЕННЯ}

Метою даного дослідження є розробка заходів з запровадження на підприємстві методів керування ризиком виникнення транспортних пригод та оцінка ефективності таких заходів.

Завданнями дослідження є розробка наступних процедур:

- виявлення та ідентифікації ризиків;

- ідентифікації ризиків;

- аналізу ризиків;

- кількісної оцінки ризиків.

\section{РЕЗУЛЬТАТИ ДОСЛІДЖЕНЬ}

Поліпшення стану з безпекою руху на транспорті може бути досягнуто шляхом запровадження на підприємстві системи керування ризиками щодо транспортних пригод, основні елементи якої визначені у ДСТУ IEC/ISO 31010.

Цілями управління ризиками щодо транспортних пригод є:

•забезпечення впевненості, що система управління ризиками може досягти запланованих результатів;

•збереження активів підприємства;

-попередження або зменшення небажаних впливів;

•забезпечення безперервного поліпшення безпечності пасажирських перевезень.

Керування ризиками щодо транспортних пригод має здійснюватися відділом безпеки руху підприємства, який підпорядковується заступнику директора з експлуатації та перевезень.

Рекомендується застосовувати наступну послідовність і взаємодію під час управління ризиками (далі процес), що показана на рисунку 1.

Виявлення та ідентифікація ризику (вихідні дані процесу) виконують на підставі аналізу документів, що стосуються операційного забезпечення відповідності технічного стану рухомого складу та безпечності перевезення пасажирів. Ідентифікація ризиків спрямована на своєчасне виявлення і реєстрацію можливих подій, які можуть негативно вплинути на досягнення цілей i завдань, поставлених перед відділом і кожним його працівником.

Ідентифікація ризиків проводиться як 3 точки зору минулого досвіду, так і 3 точки зору майбутніх можливих подій.

Аналіз ризиків виконується 3 метою виділення критичних подій. Аналіз рекомендується здійснювати у контрольних точках процесу керування ризиками, приклад яких поданий у таблиці 1.

У галузі транспорту пропонується контрольними точками процесу визнати такі:

- підготовлення транспортного засобу до випуску на лінію (маршрут), тобто забезпечення відповідності рухомого складу вимогам, які забезпечують його безпечну експлуатацію (точка 1);

- виконання транспортної роботи (перевезення пасажирів), тобто відповідності дій водія вимогам правил дорожнього руху, настанов щодо експлуатації транспортного засобу, інструкцій водія (точка 2). 


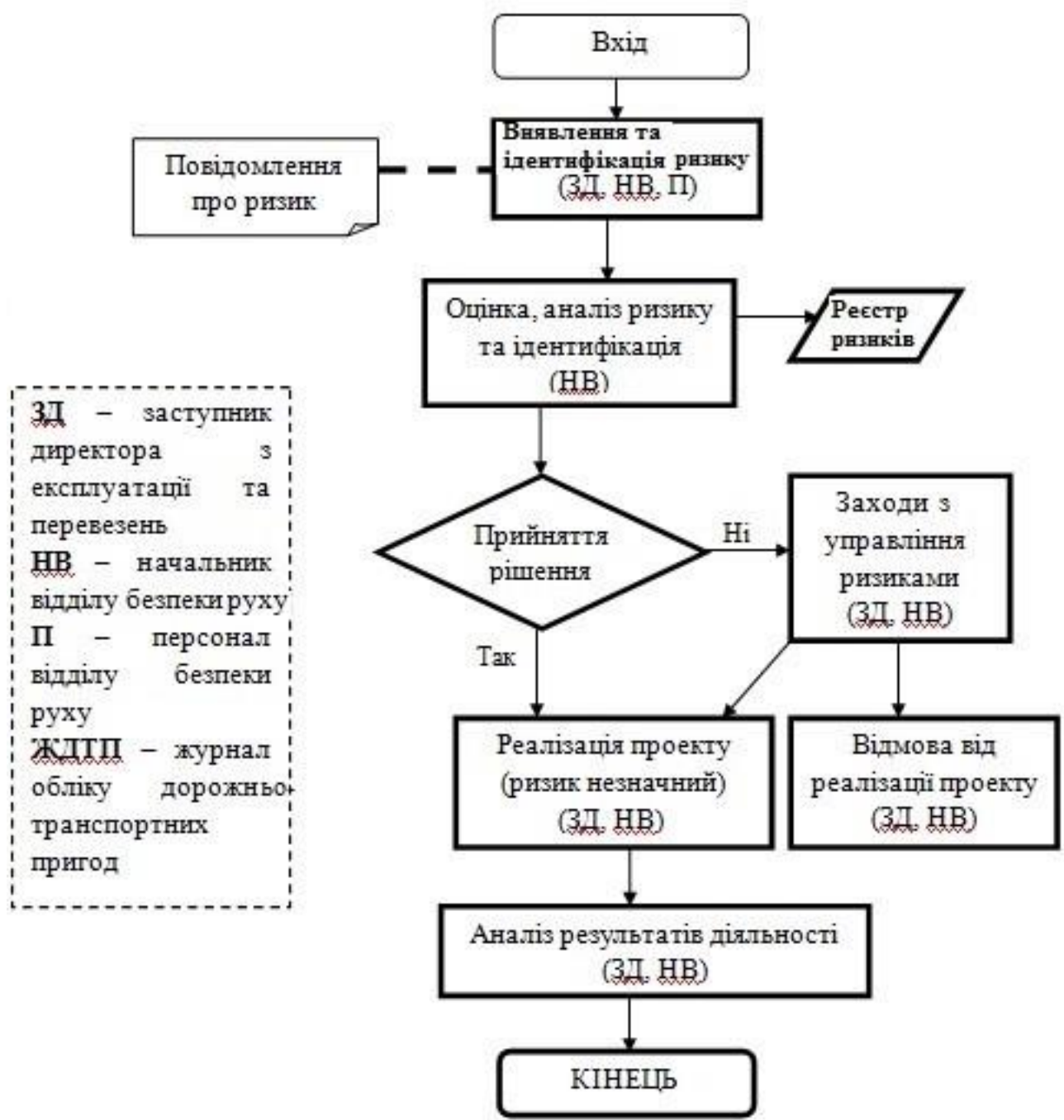

Рисунок 1 - Рекомендована послідовність дій і взаємодія під час управління ризиками в підприємстві транспорту

Таблиця 1 - Приклад контрольних точок процесу керування ризиками під час аналізу, що проводиться 3 метою виділення критичних подій

\begin{tabular}{|c|c|c|c|c|}
\hline $\begin{array}{c}\text { Контрольна } \\
\text { точка процесу }\end{array}$ & $\begin{array}{c}\text { Значення } \\
\text { параметрів та їх } \\
\text { допустимі } \\
\text { границі }\end{array}$ & $\begin{array}{c}\text { Методика } \\
\text { контролю } \\
\text { параметрів } \\
\text { процесу }\end{array}$ & $\begin{array}{c}\text { Впливові } \\
\text { фактори }\end{array}$ & $\begin{array}{l}\text { Ідентифіковані } \\
\text { ризики }\end{array}$ \\
\hline 1 & 2 & 3 & 4 & 5 \\
\hline Точка 1 & $\begin{array}{l}\text { Визначені } \\
\text { технологічною } \\
\text { документацією на } \\
\text { технічне } \\
\text { обслуговування } \\
\text { та ремонт } \\
\text { рухомого складу, } \\
\text { а також } \\
\text { Правилами } \\
\text { експлуатації КТЗ, } \\
\text { трамвая та } \\
\text { тролейбуса }\end{array}$ & $\begin{array}{l}\text { Визначена, } \\
\text { технологічною } \\
\text { документацією } \\
\text { на технічне } \\
\text { обслуговування } \\
\text { та ремонт } \\
\text { рухомого } \\
\text { складу, а також } \\
\text { ГКН 00.005.009- } \\
2002, \\
\text { ГКН 00.005.11- } \\
2003\end{array}$ & $\begin{array}{l}\text { 1. Некваліфіковані } \\
\text { дії робітників під } \\
\text { час виконання } \\
\text { технічного } \\
\text { обслуговування та } \\
\text { ремонту. } \\
\text { 2. Недоліки } \\
\text { технічної } \\
\text { документації. } \\
\text { 3. Браковані або } \\
\text { невідповідні } \\
\text { складові рухомого } \\
\text { складу. } \\
\text { 4. Відмова або }\end{array}$ & $\begin{array}{l}\text { Невідповідність } \\
\text { рухомого складу } \\
\text { визначеним } \\
\text { характеристикам }\end{array}$ \\
\hline
\end{tabular}


() Андрусенко С.I., Бугайчук О.С., Будниченко В.Б., Подпіснов В.С. 2021

\begin{tabular}{|c|c|c|c|c|}
\hline 1 & 2 & 3 & 4 & 5 \\
\hline & & & $\begin{array}{l}\text { застосування } \\
\text { непридатного } \\
\text { технологічного } \\
\text { устаткування. } \\
\end{array}$ & \\
\hline Точка 2 & $\begin{array}{l}\text { Визначені } \\
\text { Правилами } \\
\text { дорожнього руху } \\
\text { України, } \\
\text { Правилами } \\
\text { експлуатації } \\
\text { трамвайних } \\
\text { вагонів, } \\
\text { інструкція водія }\end{array}$ & $\begin{array}{l}\text { Визначена, } \\
\text { технологічною } \\
\text { документацією } \\
\text { на маршрут, } \\
\text { Положенням про } \\
\text { відділ безпеки } \\
\text { руху } \\
\text { підприємства }\end{array}$ & $\begin{array}{l}\text { 1. Некваліфіковані } \\
\text { дії водія. } \\
\text { 2. Несприятливі } \\
\text { метеорологічні } \\
\text { умови. }\end{array}$ & $\begin{array}{l}\text { Невідповідність } \\
\text { дій водія }\end{array}$ \\
\hline
\end{tabular}
таблиці 2.

Приклад інформації для управління ідентифікованими ризиками (реєстр ризиків) поданий у

Таблиця 2 - Реєстр ризиків

\begin{tabular}{|c|c|c|c|c|}
\hline $\begin{array}{c}\text { Ідентифі- } \\
\text { ковані ризики }\end{array}$ & $\begin{array}{c}\text { Методи } \\
\text { контролю } \\
\text { ризику }\end{array}$ & $\begin{array}{c}\text { Дії щодо мінімізації або } \\
\text { усунення ризику }\end{array}$ & $\begin{array}{c}\text { Термін } \\
\text { проведення } \\
\text { дій щодо } \\
\text { мінімізації } \\
\text { або усунення } \\
\text { ризику } \\
\end{array}$ & $\begin{array}{c}\text { Відповідальний за } \\
\text { управління ризиком }\end{array}$ \\
\hline 1 & 2 & 3 & 4 & 6 \\
\hline $\begin{array}{l}\text { Невідповід- } \\
\text { ність } \\
\text { технічного } \\
\text { стану } \\
\text { рухомого } \\
\text { складу }\end{array}$ & $\begin{array}{c}\text { Аналіз } \\
\text { першо- } \\
\text { причин } \\
\text { згідно з } \\
\text { додатком } \\
\text { A ДСТУ } \\
\text { IEC/ISO } \\
31010\end{array}$ & $\begin{array}{l}\text { Згідно з додатком В.1 ДСТУ } \\
\text { IEC/ISO 31010, а також: } \\
\text { 1. Додаткове навчання } \\
\text { персоналу. } \\
\text { 2. Проведення додаткової } \\
\text { перевірки технологічної } \\
\text { документації на технічне } \\
\text { обслуговування та ремонти. } \\
\text { 3. Зміна постачальника } \\
\text { складової. } \\
\text { 4. Позачергова перевірка } \\
\text { технічного стану або } \\
\text { зменшення періодичності } \\
\text { його виконання. } \\
\text { 5. Позачергова перевірка або } \\
\text { зменшення періодичності } \\
\text { перевірки устаткування. }\end{array}$ & $\begin{array}{c}\text { Відповідно до } \\
\text { запланова- } \\
\text { них заходів }\end{array}$ & $\begin{array}{l}\text { Начальник відділу } \\
\text { безпеки руху }\end{array}$ \\
\hline $\begin{array}{l}\text { Невідповід- } \\
\text { ність дій } \\
\text { водія }\end{array}$ & $\begin{array}{c}\text { Аналіз } \\
\text { першо- } \\
\text { причин } \\
\text { згідно з } \\
\text { додатком } \\
\text { A ДCTУ } \\
\text { IEC/ISO } \\
31010\end{array}$ & $\begin{array}{l}\text { Згідно з додатком В.1 ДСТУ } \\
\text { IEC/ISO 31010: } \\
\text { 1. Додаткове навчання } \\
\text { водіїв. } \\
\text { 2. Позачергова перевірка } \\
\text { тривалості робочої зміни } \\
\text { водіїв. } \\
\text { 3. Позачергова медична } \\
\text { перевірка водіїв. } \\
\text { 4. Відсторонення від роботи } \\
\text { водія. }\end{array}$ & $\begin{array}{c}\text { Відповідно до } \\
\text { запланова- } \\
\text { них заходів }\end{array}$ & $\begin{array}{c}\text { Начальник відділу } \\
\text { безпеки руху }\end{array}$ \\
\hline
\end{tabular}


Реєстр ризиків рекомендується періодично переглядати, 3 метою уточнення та доповнення виявленими ризиками.

Крім того рекомендується, щоб будь-який співробітник відділу безпеки руху, незалежно від займаної посади, отримавши інформацію про будь-який ризик, негайно повідомляв про це начальника відділу.

Кількісний аналіз ризиків рекомендується проводити уповноваженій особі відділу безпеки руху, щоб визначити ступінь пріоритетності ризику, який розраховується за індикатором (коефіцієнт безпеки руху), що обчислюється згідно 3, наприклад, ГКН 00.005.009-2002 для транспортних підприємств міського електричного транспорту для маршрутів та в цілому для підприємства за встановлений період часу.

Рекомендовані критерії та ступені наслідків ризиків подані в таблиці 3.

Таблиця 3 - Критерії та ступені наслідків ризиків

\begin{tabular}{|c|c|c|c|}
\hline \multicolumn{2}{|c|}{ Оцінка за ГКН 00.005.009-2002 } & \multicolumn{2}{|r|}{ Ризики } \\
\hline $\begin{array}{c}\text { Значення } \\
\text { індикатора* }\end{array}$ & Оцінка & Рейтинг & Серйозність наслідків \\
\hline менше 0,6 & Незадовільно & $\begin{array}{l}\text { Серйозний (значущий) } \\
\text { рівень }\end{array}$ & $\begin{array}{l}\text { Неможливість допуску } \\
\text { транспортного засобу (має бути } \\
\text { списаний) або водія (має бути } \\
\text { звільнений) до пасажирських } \\
\text { перевезень. Значні збитки для } \\
\text { підприємства }\end{array}$ \\
\hline 0,6 до 0,75 & Задовільно & Помірний рівень & $\begin{array}{l}\text { Довготривала неможливість } \\
\text { допуску транспортного засобу або } \\
\text { водія до пасажирських перевезень. } \\
\text { Значні збитки для підприємства }\end{array}$ \\
\hline 0,76 до 0,91 & Добре & Низький рівень & $\begin{array}{l}\text { Короткотривала неможливість } \\
\text { допуску транспортного засобу або } \\
\text { водія до пасажирських перевезень. } \\
\text { Несуттєві збитки для підприємства }\end{array}$ \\
\hline більше 0,91 & Відмінно & Несуттєвий рівень & $\begin{array}{l}\text { Можливість помилкової оцінки } \\
\text { результатів. Відсутність збитків для } \\
\text { підприємства }\end{array}$ \\
\hline
\end{tabular}

Примітка *. Значення індикатора обчислюється за встановлений період часу аналогічно коефіцієнту безпеки руху, метод обчислення якого наведений у ГКН 00.005.009-2002

\section{ОБГОВОРЕННЯ РЕЗУЛЬТАТІВ ДОСЛІДЖЕННЯ}

За результатами оцінки ризику рекомендується приймати рішення щодо можливості реагування на ризик, а саме:

- зменшення ризику (виконуються дії щодо зменшення ймовірності та/або впливу ризику);

- ухилення від ризику (припинення діяльності, що веде до ризику);

- прийняття ризику (не робиться ніяких дій для того, щоб знизити ймовірність або вплив події).

За позитивних результатів оцінки приймається рішення щодо реалізації проекту (прийняття ризику).

За негативних результатів оцінки ризику, приймається рішення про відмову від реалізації проекту (уникнення ризику) або проводяться заходи щодо пом'якшення ризику та повторно оцінюється залишковий ризик після проведення таких заходів.

На підставі збору та аналізу інформації про причини виникнення ризиків та пропозицій щодо їх усунення відділ безпеки руху готує нові пропозиції з поліпшення безпеки пасажирських перевезень, які заслуховуються і обговорюються на нарадах щодо аналізу системи управління підприємством 3 боку керівництва.

Документування небезпечних подій, які відбулися, рекомендується здійснювати шляхом заповнення спеціального журналу реєстрації дорожньо-транспортних пригод, який має вестися на паперовому носії або у електронному вигляді. Цей журнал як мінімум має містити таку інформацію:

- дату виникнення дорожньо-транспортної пригоди; 
- номер рухомої одиниці;

- табельний номер водія;

- причину виникнення дорожньо-транспортної пригоди;

- заходи, що пропонуються для уникнення аналогічної події в подальшому.

Під час аналізування результативності процесу керування ризиками керівник процесу (як правило, начальник відділу безпеки руху) визначає досягнення запланованих характеристик процесу. Періодичність аналізування 1 раз на квартал. Результати аналізування у довільній формі надаються вищому керівництву - заступнику директора 3 експлуатації та перевезень для аналізування функціонування системи управління якістю. До результатів аналізування можуть заноситись пропозиції щодо вдосконалення процесу. Інформація щодо ступеня досягнення процесом необхідних характеристик може бути подана у вигляді таблиць або графіків для забезпечення наочності простеження тенденцій погіршення або поліпшення процесу.

\section{ВИСНОВКИ}

Показано, що організація повинна визначати ризики та можливості, які потрібно враховувати для забезпечення впевненості в тому, що підприємство може досягти запланованого результату 3 точки зору зменшення кількості дорожньо-транспортних пригод.

Організація має планувати та інтегрувати в процеси управління дії стосовно цих ризиків і можливостей. Необхідно оцінювати результативність таких дій.

Ризики мають бути ідентифіковані та започаткований процес аналізу ризиків. Пропонується контрольними точками процесу визнати такі: невідповідність технічного стану рухомого складу вимогам, які визначають його безпечну експлуатацію (точка 1); невідповідність дій водія вимогам правил дорожнього руху, настанов щодо експлуатації транспортного засобу, інструкцій водія (точка 2). Має складатися реєстр ризиків проводитись кількісний аналіз ризиків, де підраховується значення індикатору ризику, наприклад, відповідно до документу ГКН 00.005.009-2002. Необхідно розробляти рекомендації щодо зменшення ризику шляхом ухилення від ризику (припинення діяльності, що веде до ризику) або прийняття ризику (не виконується ніяких дій для зниження ймовірності або впливу події). Подальше дослідження має бути спрямоване на розширення реєстру ризиків діяльності на транспорті та удосконалення методів оцінки запровадження в підприємстві системи управління ризиками.

\section{ПЕРЕЛІК ДЖЕРЕЛ ПОСИЛАННЯ}

1.Про єдині вимоги до конструкції та технічного стану колісних транспортних засобів, що експлуатуються : Постанова Кабінету Міністрів України від 22 грудня 2010 р. № 1166. Додаток «Класифікація колісних транспортних засобів». URL: https://www.kmu.gov.ua/npas/243939925.

2.Про Правила дорожнього руху : Постанова Кабінету Міністрів України від 10 жовтня 2001 p. № 1306. Київ. Документ 1306-2001-п, чинний, поточна редакція. Редакція від 20.07.2021 p. URL: https://www.rada.gov.ua .

3. Державна інспекція України 3 безпеки на наземному транспорті : Наказ «Про затвердження Заходів 3 покращення безпеки дорожнього руху на міському електричному транспорті України (трамвай, тролейбус) в 2014 році» від 28.11.2013 p. № 945. URL: https://docs.dtkt.ua/ru/download/pdf/1041.57121.1.

4. Про затвердження Методичних рекомендацій з питань безпеки автомобільних перевезень : Наказ Міністерства транспорту України від 19.09.2003 p. № 111. URL: http://online.budstandart.com/ua/catalog/doc-page.html?id_doc=71859.

5.Про затвердження критеріїв, за якими оцінюється ступінь ризику від провадження господарської діяльності у сфері автомобільного транспорту та визначається періодичність проведення планових заходів державного нагляду (контролю) Державною службою з безпеки на транспорті : Постанова Кабінету Міністрів України від 15 січня 2020 р. № 7. Київ. Документ 7-2020п, чинний, поточна редакція. Прийняття від 15.01.2020 p. URL: https://zakon.rada.gov.ua/laws/show/72020-\%D0\%BF\#Text .

6. Типове Положення про Систему управління безпекою руху на автомобільному транспорті (на всіх рівнях - міністерство - підприємство) : Додаток до наказу Міністерства транспорту України від 12.11.2003 p. № 877. URL: https://zakon.rada.gov.ua/rada/show/v087736103\#Text. 
7.Про затвердження Положення про організацію проведення виробничих інструктажів та навчання водіїв трамвайних вагонів і тролейбусів. Документ z0528-04, чинний, поточна редакція. Прийняття від 23.01.2004 p. URL: https://zakon.rada.gov.ua/laws/show/z0528-04\#Text .

8.Про затвердження Порядку технічного розслідування дорожньо-транспортних пригод, катастроф, аварій на автомобільному та міському електричному (трамвай, тролейбус) транспорті [Електронний ресурс] : Наказ Міністерства інфраструктури України від 23.06.2015 р. № 231. Режим доступу: https://zakon.rada.gov.ua/laws/show/z0818-15.

9.Про затвердження Порядку технічного розслідування катастроф, аварій, дорожньотранспортних пригод, подій на залізничному транспорті [Електронний ресурс] : Наказ Міністерства інфраструктури України. від 21.09.2018 p. № 433. Режим доступу: https://zakon.rada.gov.ua/laws/show/z1185-18\#Text.

10.Про затвердження Положення про класифікацію, порядок розслідування та обліку аварійних морських подій із суднами [Електронний ресурс] : Наказ Міністерства транспорту та зв’язку України від 29.05.2006 р. № 516. Режим доступу: https://zakon.rada.gov.ua/laws/show/z095906\#Text.

11.Система управління безпекою руху на автомобільному транспорті [Електронний ресурс] : посібник Міністерства інфраструктури України. Режим доступу: https://mtu.gov.ua/files/GUIDE_ua_2016.pdf .

12.Правила експлуатації трамвая і тролейбуса : Наказ Міністерства інфраструктури України від 03.02.2020 р. № 36, зареєстровано в Міністерстві юстиції України від 17 квітня 2020 р. № 353/34636. Режим доступу: https://zakon.rada.gov.ua/laws/show/z0353-20\#Text .

13. Інструкція водія тролейбуса (код КП 8323) : КП «Київпастранс». Тролейбусне ремонтно-експлуатаційне депо № 2.

URL: https://dostup.pravda.com.ua/request/69619/response/169912/attach/11/2.pdf .

14.ГКН 00.005.009-2002. Безпека дорожнього руху на міському електротранспорті. Організація оперативного контролю за безпекою руху.

15.ГКН 00.005.11-2003. Безпека дорожнього руху на міському електротранспорті. Порядок службового розслідування і розбору дорожньо-транспортних пригод.

16. Кульбашна Н.І. Конспект лекцій з дисципліни «Безпека руху та гальмівні системи» (для студентів 4 курсу денної та заочної форм навчання за напрямом підготовки 6.050702 «Електромеханіка» та слухачів другої вищої освіти спеціальності 7.05070203 «Електричний транспорт»). Харків : Харк. нац. акад. міськ. госп-ва, 2012. 80 с. URL: https://core.ac.uk/download/pdf/11336415.pdf.

17. Ткаченко І.О. Ризики у транспортних процесах : навчальний посібник. Харків : ХНУМГ ім. О.М. Бекетова, 2017. 114 с. URL: https://core.ac.uk/download/pdf/154806543.pdf .

18.Сафонов Ю.М., Ленська Н.І. Класифікація ризиків у державному регулюванні пасажирського автомобільного транспортного комплексу. Причорноморські економічні студї. Економіка та управління національним господарством. 2017. Випуск 14. С. 47-52. URL: http://bses.in.ua/journals/2017/14_2017/12.pdf .

19. Івасишина Н.В., Малашенко Ю.А. Фактори, що впливають на імовірність настання ДТП та враховуються при тарифікації. Наукові записки. Серія «Економіка». 2012. Випуск 19. С. 340 342. URL: http://ecj.oa.edu.ua/articles/2012/n19/77.pdf

20.Донець Л.І. Економічні ризики та методи їх вимірювання: навчальний посібник. Київ : Центр навчальної літератури, 2006. 312 с.

21.Самсонкін В.М., Мойсеєнко В.І. Теорія безпеки на залізничному транспорті : монографія. Київ : Каравела, 2014. 248 с.

22.Хаккер А.С., Браймайстер Л. Використання впливів і ризиків у дослідженнях з безпеки дорожнього руху. Нідерланди, Лейдсендам : Інститут SWOV з дослідження безпеки дорожнього pyxy, 2001.

23.Kristiansen S. Maritime Transportation: Safety Management and Risk Analysis. Elsevier Butterworth-Heinemann, 2005. 508 p.

24. ДСТУ IEC/ISO 31010-2013 (IEC/ISO 31010:2009, IDT). Керування ризиком. Методи загального оцінювання ризику. URL: https://khoda.gov.ua/image/catalog/files/dstu\%2031010.pdf .

25.ДСТУ ISO Guide 73-2013 (ISO Guide 73:2009, IDT). Керування ризиком. Словник термінів. Метрологія. Національний стандарт України. [Електронний ресурс]. Режим доступу: https://metrology.com.ua/ntd/skachat-iso-iecohsas/iso/dstu-iso-guide-73-2013/. 
26.IEC 31010:2019. Risk management - Risk assessment techniques. International Organization for Standardization. [Електронний ресурс]. Режим доступу: https://www.iso.org/standard/72140.html .

27.ISO 31000:2018. Risk management [Електронний ресурc]. International Organization for Standardization. Режим доступу: https://www.iso.org/files/live/sites/isoorg/files/store/en/PUB100426.pdf .

28.ДСТУ ISO 9001-2015 (ISO 9001:2015, IDT). Системи управління якістю. Вимоги. URL: https://khoda.gov.ua/image/catalog/files/\%209001.pdf .

\section{REFERENCES}

1. Pro yedyni vymohy do konstruktsii ta tekhnichnoho stanu kolisnykh transportnykh zasobiv, shcho ekspluatuiutsia (2010) : Postanova Kabinetu Ministriv Ukrainy vid 22 hrudnia 2010 r. №1166. Dodatok «Klasyfikatsiia kolisnykh transportnykh zasobiv». URL: https://www.kmu.gov.ua/npas/243939925.

2.Pro Pravyla dorozhnoho rukhu (2021) : Postanova Kabinetu Ministriv Ukrainy vid 10 zhovtnia 2001 r. № 1306. Kyiv. Dokument 1306-2001-p, chynnyi, potochna redaktsiia. Redaktsiia vid 20.07.2021 r. URL: https://www.rada.gov.ua .

3. Derzhavna inspektsiia Ukrainy z bezpeky na nazemnomu transporti (2013) : Nakaz «Pro zatverdzhennia Zakhodiv $\mathrm{z}$ pokrashchennia bezpeky dorozhnoho rukhu na miskomu elektrychnomu transporti Ukrainy (tramvai, troleibus) v 2014 rotsi» vid 28.11.2013 r. № 945.

URL: https://docs.dtkt.ua/ru/download/pdf/1041.57121.1.

4.Pro zatverdzhennia Metodychnykh rekomendatsii z pytan bezpeky avtomobilnykh perevezen (2003) : Nakaz Ministerstva transportu Ukrainy vid 19.09.2003 r. № 111 . URL: http://online.budstandart.com/ua/catalog/doc-page.html?id doc $=71859$.

5.Pro zatverdzhennia kryteriiv, za yakymy otsiniuietsia stupin ryzyku vid provadzhennia hospodarskoi diialnosti u sferi avtomobilnoho transportu ta vyznachaietsia periodychnist provedennia planovykh zakhodiv derzhavnoho nahliadu (kontroliu) Derzhavnoiu sluzhboiu z bezpeky na transporti (2020) : Postanova Kabinetu Ministriv Ukrainy vid 15 sichnia 2020 r. № 7. Kyiv. Dokument 7-2020-p, chynnyi, potochna redaktsiia. Pryiniattia vid 15.01.2020 r.

URL: https://zakon.rada.gov.ua/laws/show/7-2020-\%D0\%BF\#Text .

6.Typove Polozhennia pro Systemu upravlinnia bezpekoiu rukhu na avtomobilnomu transporti (na vsikh rivniakh - ministerstvo - pidpryiemstvo) (2003) : Dodatok do nakazu Ministerstva transportu Ukrainy vid 12.11.2003 r. № 877. URL: https://zakon.rada.gov.ua/rada/show/v0877361-03\#Text .

7.Pro zatverdzhennia Polozhennia pro orhanizatsiiu provedennia vyrobnychykh instruktazhiv ta navchannia vodiiv tramvainykh vahoniv i troleibusiv (2004). Dokument z0528-04, chynnyi, potochna redaktsiia. Pryiniattia vid 23.01.2004 r. URL: https://zakon.rada.gov.ua/laws/show/z0528-04\#Text .

8.Pro zatverdzhennia Poriadku tekhnichnoho rozsliduvannia dorozhno-transportnykh pryhod, katastrof, avarii na avtomobilnomu ta miskomu elektrychnomu (tramvai, troleibus) transporti (2015) [Elektronnyi resurs] : Nakaz Ministerstva infrastruktury Ukrainy vid 23.06.2015 r. № 231. Rezhym dostupu: https://zakon.rada.gov.ua/laws/show/z0818-15.

9.Pro zatverdzhennia Poriadku tekhnichnoho rozsliduvannia katastrof, avarii, dorozhnotransportnykh pryhod, podii na zaliznychnomu transporti (2018) [Elektronnyi resurs] : Nakaz Ministerstva infrastruktury Ukrainy vid 21.09.2018 r. № 433. Rezhym dostupu: https://zakon.rada.gov.ua/laws/show/z1185-18\#Text.

10.Pro zatverdzhennia Polozhennia pro klasyfikatsiiu, poriadok rozsliduvannia ta obliku avariinykh morskykh podii iz sudnamy (2006) [Elektronnyi resurs] : Nakaz Ministerstva transportu ta zviazku Ukrainy vid 29.05.2006 r. № 516. Rezhym dostupu: https://zakon.rada.gov.ua/laws/show/z0959-06\#Text .

11.Systema upravlinnia bezpekoiu rukhu na avtomobilnomu transporti (2016) [Elektronnyi resurs] : posibnyk Ministerstva infrastruktury Ukrainy. Rezhym dostupu: https://mtu.gov.ua/files/GUIDE_ua_2016.pdf.

12.Pravyla ekspluatatsii tramvaia i troleibusa (2020) : Nakaz Ministerstva infrastruktury Ukrainy vid 03.02.2020 r. № 36, zareiestrovano v Ministerstvi yustytsii Ukrainy vid 17 kvitnia 2020 r. № 353/34636.

13.Instruktsiia vodiia troleibusa (kod KP 8323) : KP «Kyivpastrans». Troleibusne remontnoekspluatatsiine depo № 2 .

URL: https://dostup.pravda.com.ua/request/69619/response/169912/attach/11/2.pdf .

14.HKN 00.005.009-2002. (2002). Bezpeka dorozhnoho rukhu na miskomu elektrotransporti. Orhanizatsiia operatyvnoho kontroliu za bezpekoiu rukhu.

15.HKN 00.005.11-2003. (2003). Bezpeka dorozhnoho rukhu na miskomu elektrotransporti. Poriadok sluzhbovoho rozsliduvannia i rozboru dorozhno-transportnykh pryhod. 
16.Kulbashna N.I. (2012). Konspekt lektsii z dystsypliny «Bezpeka rukhu ta halmivni systemy» (dlia studentiv 4 kursu dennoi ta zaochnoi form navchannia za napriamom pidhotovky 6.050702 «Elektromekhanika» ta slukhachiv druhoi vyshchoi osvity spetsialnosti 7.05070203 «Elektrychnyi transport»). Kharkiv : Khark. nats. akad. misk. hosp-va, 2012, 80. URL: https://core.ac.uk/download/pdf/11336415.pdf .

17.Tkachenko I.O. (2017). Ryzyky u transportnykh protsesakh : navchalnyi posibnyk. Kharkiv : KhNUMH im. O.M. Beketova, 2017, 114. URL: https://core.ac.uk/download/pdf/154806543.pdf .

18.Safonov Yu.M., Lenska N.I. (2017). Klasyfikatsiia ryzykiv u derzhavnomu rehuliuvanni pasazhyrskoho avtomobilnoho transportnoho kompleksu. Prychornomorski ekonomichni studii. Ekonomika ta upravlinnia natsionalnym hospodarstvom. 2017, 14, 47-52.

URL: http://bses.in.ua/journals/2017/14_2017/12.pdf .

19.Ivasyshyna N.V., Malashenko Yu.A. (2012). Faktory, shcho vplyvaiutsia na ymovirnist nastannia DTP ta vrakhovuiutsia pry taryfikatsii. Naukovi zapysky. Seriia «Ekonomika». 2012, 19, 340-342. URL: http://ecj.oa.edu.ua/articles/2012/n19/77.pdf

20.Donets L.I. (2006). Ekonomichni ryzyky ta metody yikh vymiriuvannia: navchalnyi posibnyk. Kyiv : Tsentr navchalnoi literatury, 2006, 312.

21.Samsonkin V.M., Moiseienko V.I. (2014). Teoriia bezpeky na zaliznychnomu transporti : monohrafiia. Kyiv : Karavela, 2014, 248.

22.Khakker A.S., Braimaister L. (2001). Vykorystannia vplyviv i ryzykiv u doslidzhenniakh z bezpeky dorozhnoho rukhu. Niderlandy, Leidsendam : Instytut SWOV z doslidzhennia bezpeky dorozhnoho rukhu, 2001.

23.Kristiansen S. (2005). Maritime Transportation: Safety Management and Risk Analysis. Elsevier Butterworth-Heinemann, 2005, 508.

24.DSTU IEC/ISO 31010-2013 (IEC/ISO 31010:2009, IDT). (2013). Keruvannia ryzykom. Metody zahalnoho otsiniuvannia ryzyku. URL: https://khoda.gov.ua/image/catalog/files/dstu\%2031010.pdf .

25.DSTU ISO Guide 73-2013 (ISO Guide 73:2009, IDT). (2013). Keruvannia ryzykom. Slovnyk terminiv. Metrolohiia. Natsionalnyi standart Ukrainy. [Elektronnyi resurs]. Rezhym dostupu: https://metrology.com.ua/ntd/skachat-iso-iecohsas/iso/dstu-iso-guide-73-2013/.

26.IEC 31010:2019. (2019). Risk management - Risk assessment techniques. International Organization for Standardization. [Elektronnyi resurs]. Rezhym dostupu: https://www.iso.org/standard/72140.html .

27.ISO 31000:2018. (2018). Risk management [Elektronnyi resurs]. International Organization for Standardization. Rezhym dostupu: https://www.iso.org/files/live/sites/isoorg/files/store/en/PUB100426.pdf .

28.DSTU ISO 9001-2015 (ISO 9001:2015, IDT). (2015). Systemy upravlinnia yakistiu. Vymohy. URL: https://khoda.gov.ua/image/catalog/files/\%209001.pdf .

\section{S. Andrusenko, O. Buhaichuk, V. Budnychenko, V. Podpisnov. Use of risk management methods to reduce transport accidents.}

This article contains an analysis of regulations, scientific and educational as well as practical work on transport accidents reducing and risk management methods using to achieve this purpose.

It is shown that a company must identify the risks and opportunities that need to be taken into account for achieving the planned result as well as increasing the number of desired effects, side effects prevention or reducing and improvement achieving.

The company should plan and integrate actions regarding these risks and opportunities into management processes. It is necessary to evaluate the effectiveness of such actions.

Risks are supposed to be identified as well as risk analysis process are supposed to be initiated. It is proposed to recognize the following as the process control points: non-compliance of the rolling stock technical condition with the requirements that determine its safe operation (point 1); driver's actions noncompliance with the requirements of traffic rules as well as operation instructions for the vehicle and driver's instructions (point 2).

The risk register is compiled. A quantitative risk analysis is performed. It contains the value of the risk indicator, for example, in accordance with HKN 00.005.009-2002. Then there were recommendations to reduce the risk by avoiding the risk (cessation of activities that lead to risk) or accepting the risk (no action is taken to reduce the event likelihood or its impact). Further research should be aimed at expanding the risk register for transport activities and improving the methods for risk management assessing in the company. 
Key words: transport, traffic safety, accident, risk, management, analysis, process, control points, risk identifier, risk register.

АНДРУСЕНКО Сергій Іванович, кандидат технічних наук, професор, завідувач кафедри технічної експлуатації автомобілів та автосервісу, Національний транспортний університет е-таil: sergeandrusenko@gmail.com. http://orcid.org/0000-0002-9914-0200

БУГАЙЧУК Олександр Сергійович, кандидат технічних наук, доцент, доцент кафедри технічної експлуатації автомобілів та автосервісу, Національний транспортний університет e-mail: bug_os@ukr.net. http://orcid.org/0000-0001-8646-6263

БУДНИЧЕНКО Валерій Борисович, кандидат технічних наук, доцент, доцент кафедри технічної експлуатації автомобілів та автосервісу, Національний транспортний університет e-mail: budnvb@i.ua. http://orcid.org/0000-0002-1235-3781

ПОДПІСНОВ Владислав Сергійович, старший викладач кафедри технічної експлуатації автомобілів та автосервісу, Національний транспортний університет e-mail: vpodpisnov@ukr.net. http://orcid.org/0000-0002-8583-1502

Serhii ANDRUSENKO, Ph.D. in Technical Science, Professor, Head of the Department of Motor Vehicle Maintenance and Servicing, Kyiv, National Transport University e-mail: sergeandrusenko@gmail.com. http://orcid.org/0000-0002-9914-0200

Oleksandr BUHAICHUK, Ph.D. in Technical Science, Associate Professor, Associate Professor of the Department of Motor Vehicle Maintenance and Servicing, Kyiv, National Transport University e-mail: bug_os@ukr.net. http://orcid.org/0000-0001-8646-6263

Valerii BUDNYCHENKO, Ph.D. in Technical Science, Associate Professor, Associate Professor of the Department of Motor Vehicle Maintenance and Servicing, Kyiv, National Transport University e-mail: budnvb@i.ua. http://orcid.org/0000-0002-1235-3781

Vladyslav PODPISNOV, Senior Lecturer of the Department of Motor Vehicle Maintenance and Servicing, Kyiv, National Transport University e-mail: vpodpisnov@ukr.net. http://orcid.org/0000-0002$\underline{8583-1502}$

DOI 10.36910/automash.v2i17.632 